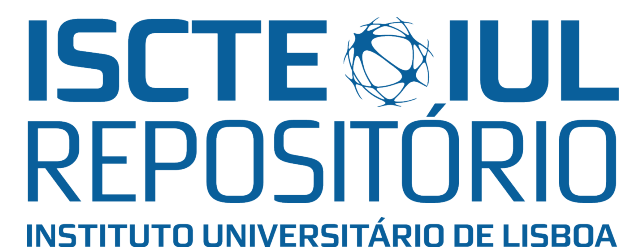

Repositório ISCTE-IUL

Deposited in Repositório ISCTE-IUL:

2019-05-22

Deposited version:

Post-print

Peer-review status of attached file:

Peer-reviewed

Citation for published item:

Santos, M. R. C., Laureano, R. M. S. \& Moro, S. (2019). Unveiling research trends for organizational reputation in the nonprofit sector. Voluntas. N/A, 1-15

Further information on publisher's website:

10.1007/s11266-018-00055-7

Publisher's copyright statement:

This is the peer reviewed version of the following article: Santos, M. R. C., Laureano, R. M. S. \& Moro, S. (2019). Unveiling research trends for organizational reputation in the nonprofit sector. Voluntas. N/A, 1-15, which has been published in final form at https://dx.doi.org/10.1007/s11266-018-000557. This article may be used for non-commercial purposes in accordance with the Publisher's Terms and Conditions for self-archiving.

Use policy

Creative Commons CC BY 4.0

The full-text may be used and/or reproduced, and given to third parties in any format or medium, without prior permission or charge, for personal research or study, educational, or not-for-profit purposes provided that:

- a full bibliographic reference is made to the original source

- a link is made to the metadata record in the Repository

- the full-text is not changed in any way

The full-text must not be sold in any format or medium without the formal permission of the copyright holders. 


\title{
Unveiling research trends for organizational reputation in the nonprofit sector
}

\author{
Abstract \\ Public scrutiny and the need for funds in a more competitive environment are pressuring \\ nonprofits to be more consciously aware of their reputation. This study used automated analysis \\ with text mining and topic modeling of 177 articles directly linked to nonprofits' reputation and \\ published up to 2016. After identifying the most salient topics and conducting an in-depth, \\ critical review of the most significant articles within each topic, four theoretical and managerial \\ implications were identified. First, managers need to develop skills to deal with risk, the Internet, \\ and social networks. Second, risk management is an emergent, still tentative, but important topic \\ waiting for more contributions. Third, researchers can apply lexicons developed and validated by \\ experts to uncover knowledge relevant to the entire nonprofit sector's organizations. Last, the \\ trends and topics highlighted can help scholars and practitioners make better decisions in \\ research or responses to management challenges.
}

Keywords: nonprofit organizations; reputation; text mining; topic modeling 


\section{Introduction}

Reputation as a social construct (Barnett et al. 2006) is considered a significant aspect of organizational strategy due to reputation's influence on perceived organizational effectiveness (Mitchell 2015) and, consequently, on resource attraction (Padanyi and Gainer 2003). Thus, reputational status is an asset for which organizations compete by developing strategies that can have positive impacts on or damage these entities' reputation (Comyns and Franklin-Johnson 2018).

Under the current competitive conditions in the nonprofit sector, managers are usually deeply concerned about preserving their organizations' reputation, as this has become a factor in their success and sustainability (Campbell 2007). Various researchers have, therefore, devoted attention to studying reputation's impact on effectiveness in the nonprofit sector (Mitchell and Stroup 2016; Padanyi 2003). Recent studies have provided support for a theoretical framework based on the rationale that appropriate accountability and transparency allow nonprofits to safeguard their legitimacy and reputation (Carvalho et al. 2017).

Given the importance of transparency practices, scholars have called for further research that analyzes how legitimacy and reputation leverage nonprofits' interactions with external actors (Lecy et al. 2012) - a key aspect of the institutional theory of nonprofit organizations (Carman 2011). This theory suggests that transparency practices are part of the structures and procedures that nonprofits can adopt to be accepted as legitimate and reputable enough for public and private grants (Dimaggio and Powell 1983). These practices, however, need to be adapted to fit the particularities of the nonprofits sector, which are distinct from other sectors (Witesman 2016). 
Given the considerable body of knowledge available on nonprofits' reputation in journals from quite distinct disciplines, scholars and practitioners in the nonprofit sector could benefit from a fuller understanding of the topics already studied and research gaps in reputation studies. To achieve this goal, appropriate techniques must be applied that facilitate an analysis of this large quantity of literature. The present study thus explored two research questions:

(1) What salient topics, if any, characterize the literature on nonprofits' reputation? Which are the most significant topics?

(2) How can examining the relevant scientific articles on each salient topic help nonprofits manage their reputation and increase scholars' knowledge in this field?

This research included two levels of analysis to answer these questions.

First, an extensive automated literature analysis is conducted covering the entire literature directly linked with research on nonprofits' reputation published up to 2016, namely, 177 fulltext scientific articles. This technique was adopted to deal with the vast selection of literature in electronic formats available from online repositories and indexed in scientific search engines; and it has previously proven valuable in literature analyses in other research fields, such as, banking (Moro et al. 2015) and tourism (Moro and Rita 2018).

Then, a topic modeling technique is applied to identify the salient topics in the reputation literature, providing a longitudinal perspective of 35 years of the literature that highlights shifts in research on the organizational reputation of nonprofits. Finally, an in-depth analysis of the most significant articles within each salient topic was conducted to provide nonprofits' managers and scholars with useful insights into how to address nonprofits' reputational issues. 
The present research sought to uncover and understand the salient topics in reputation research on nonprofits and the extent to which scholars have addressed these topics. This study also focused on identifying current research trends in light of different organizational theories, thereby highlighting opportunities for further research and offering a different, up-to-date perspective. In addition, a comprehensive lexicon of nonprofit terms was developed that characterizes underlying concepts, thereby avoiding a lexicon limited to common core institutions of the nonprofit sector or national fads in terms. As the resulting lexicon was reviewed and validated by experts, the current findings offer novel insights into reputation management for the entire sector.

Finally, by critically analyzing the results and reviewing in depth the most significant articles within each salient topic, this study found evidence of four research paradigm changes that impact nonprofits. The results further support conclusions that can help nonprofits manage their reputation and scholars to expand the current body of knowledge in this field.

\section{Theory}

Competitive environments push organizations to design and implement strategies that help them stand out from the competition. To achieve this goal, organizations must be able to respond to their target population's specific interests so that they can be perceived as the best choice, whether as service providers or business partners (Poister and Thomas 2007).

Barnett et al. (2006) sought to develop a commonly accepted definition of corporate reputation and reached the conclusion that this is generally considered the sum of perceptions leading to an overall assessment of organizations' status. Since reputation results from an aggregation of 
perceptions, the process of creating positive reputations implies managers are able to influence collective impressions of their organization (Ashcroft 2010).

The global economy and society are supported by three sectors: public, for-profit, and nonprofit organizations. The large and varied differences between these sectors continue to be discussed in the literature, but, in general, nonprofits are defined as private, self-governed, and voluntary organizations focused on social missions (Defourny et al. 2016).

In any sector, organizations will, at some point, face crises (e.g., operational or financial) for various reasons, whether internal or external. Thus, overcoming crises is a managerial challenge that every organization must deal with to thrive in a competitive world (Christensen et al. 2016; Comyns 2018). Currently, nonprofits are facing a greater demand for accountability and transparency, as well as increased government scrutiny - a general crisis arising from fraud allegations. According to the Association of Certified Fraud Examiners' (ACFE) 2016 Report to the Nations on Occupational Fraud and Abuse, nonprofits currently lose 5 percent of their annual revenues to fraud. This issue is the result of corruption, ineffectiveness, or opportunistic practices (Burger, 2012), and fraud tends to affect public perceptions of the entire sector negatively. Although reputation can be influenced by circumstances beyond organizations' control, some scholars argue that organizations need to develop a reputational capacity themselves (Tremblay-Boire et al. 2016) in order to strengthen their image of trustworthiness.

Willems (2016) identifies continuous improvement practices as the main factor that enhances nongovernmental development organizations' ability to withstand crises. In models developed to explain how public perceptions are formed, affective and cognitive components are seen as antecedent constructs. These include quality, leadership, attractiveness, communication, 
representation, client satisfaction, effective governance, stakeholder involvement, ability to partner, and organizational social responsibility (Mitchell 2015). In contrast, performance does not appear to be consensual (Sarstedt and Schloderer 2010). These factors can determine organizations' survival since nonprofits' reputation influences potential donors' willingness to fund these institutions' activities, as well as attracting personnel, volunteers or other supporters (Gent et al. 2015; Grant and Potoski 2015; Heller 2008; Sarstedt 2010).

The nonprofit sector's stakeholders may use reputation as a reference point when making donation decisions, especially when little information is available by which to assess nonprofits' performance and effectiveness. This can be the result of a poor use of evaluation models since assessment remains a difficult and ambiguous task for nonprofits (Hull and Lio 2006; Kaplan 2001; Kendall and Knapp 2000). In this context, stakeholders' evaluations may be based on how organizations' social impacts are perceived (Anheier et al. 2013) and not on how well these organizations' overall mission is achieved (Kaplan 2001).

Given the lack of evaluation information that currently characterizes the nonprofit sector, analyses of the concept of reputation have become a priority as these can contribute to ongoing critical debates about how nonprofits can best manage their reputation. Moreover, the number of nonprofits has grown, which has made this sector even more competitive and led to a greater emphasis on building strong brand images to differentiate these organizations from their nonprofit peers. Their managers can achieve a better reputation by facing important challenges in the marketing domain such as corporate image, identity, brand, and efforts to rebrand (Gilstrap and Smith 2016). 
In recent years, nonprofits have adopted many commercial practices as part of their strategies to attract resources. However, scholars addressing this topic have found the sector has significant particularities in terms of market orientation strategies (Hume and Hume 2016; Maier et al. 2016).

Although year after year, research is published addressing the reputational aspects of nonprofits, to date, no literature analysis has been conducted with the goal of understanding the trends and shifts in research on the organizational reputation of nonprofits. Nonetheless, other reputational related topic trends are present in literature, such as philanthropy (Bekkers and Wiepking 2010), accountability (Crofts and Bisman 2010), and the effectiveness (Lecy 2012). Despite these efforts, the input data applied for such research covers a limited timeframe and distinct analysis techniques are applied, i.e. brainstorming and discussion, text mining lexicographic tool and structured literature review, respectively.

The almost total absence of holistic literature analyses that encompass a representative number of nonprofit sector studies may be due to the heterogeneity of this research, in which the terms used change depending on the field of study, country, or trends (Salamon and Sokolowski 2016; Smith et al. 2006). However, the large accumulation of published articles in recent years justifies the use of text mining and topic modeling techniques to help researchers determine a relevant set of terms and the possible relationships among them (Calheiros et al. 2017). Furthermore, an automated approach such as the one proposed here avoids limitations imposed by human subjectivity when assessing and categorizing the literature, as well as being sufficiently efficient and scalable to deal with any number of articles. 


\section{Materials and methods}

The experimental procedure followed is shown in Figure 1. Two inputs were needed: a lexicon of relevant terms for the subject under study and a collection of relevant articles.

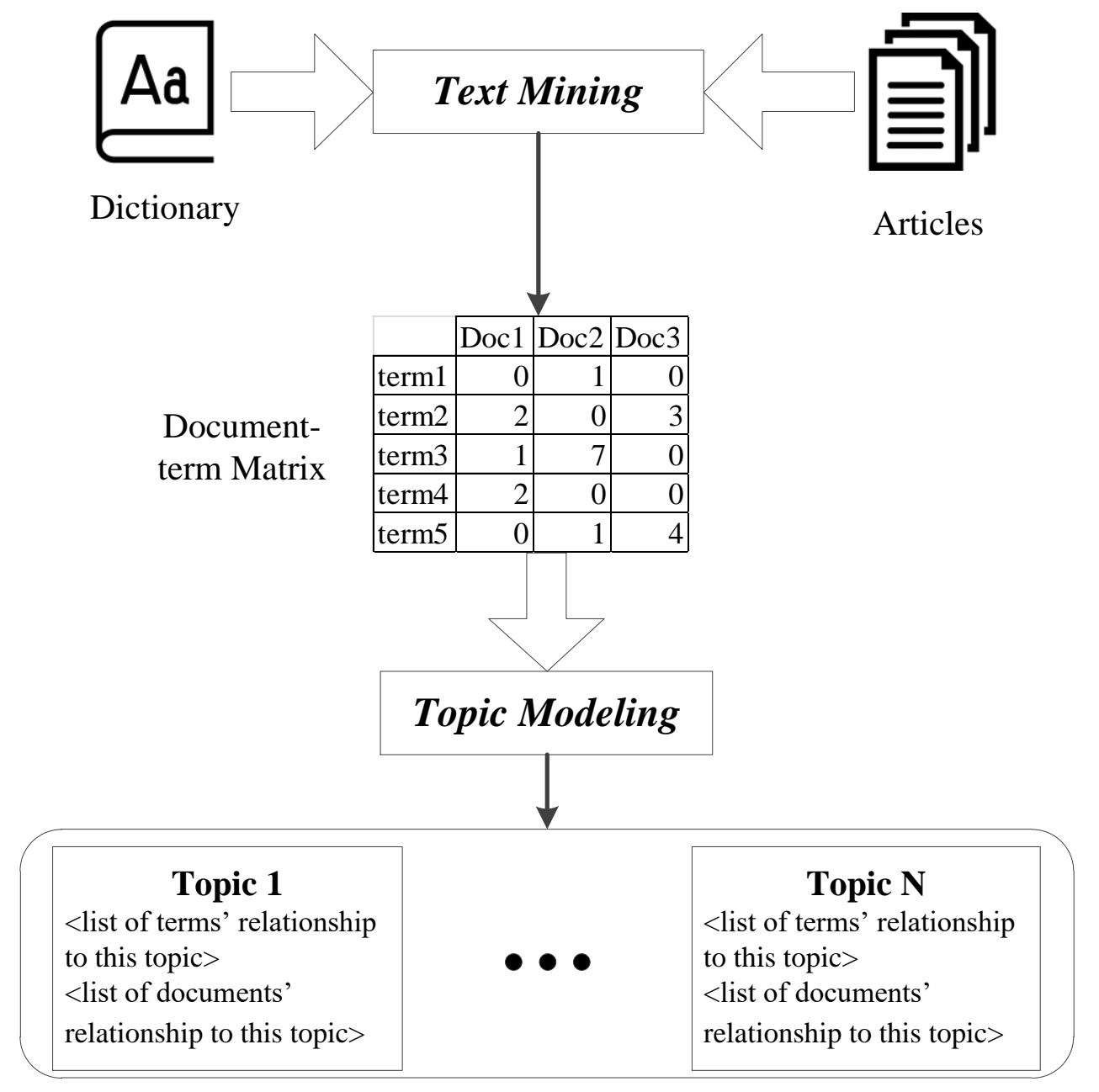

Figure 1 - Experimental procedure.

The lexicon was created by identifying the terms used by scholars and practitioners to label organizations in the nonprofit sector based on Salamon and Sokolowski (2016) and Smith et al.'s (2006) works. The present compilation also included terms that express organizational reputation based on the known lexicon (e.g., judgment, belief, opinion, reputation, estimation, and evaluation) and related concepts (e.g., image and identity) as reported by Barnett et al. (2006). 
Thus, the lexicon of relevant terms was divided into three sections: types of organizations (see Table 1), nonprofit-related items (see Table 2), and reputation terms (see Table 3). The purpose of these sections was to combine sets of words with shared meaning to be able to treat these as one single domain in the analyses. This included not only synonyms or plural forms but also terms defining different concepts that clearly fit within the same domain. For example, "motivated" and "unmotivated" or "disengagement" and "engagement" are used to describe opposite emotional associations between nonprofits and their stakeholders, but they are all used in research on factors affecting stakeholder (e.g., volunteer) retention (Curran et al. 2016). Other terms that are related to the same domain (e.g., nongovernmental organizations [NGOs], religious congregations, or social movement organizations are all nonprofits) were, nonetheless, analyzed separately because the literature includes calls for scholars to focus on the aspects that distinguish these types of institutions (Bronzetti and Veltri 2013).

Table 1 -Dictionary for the nonprofit sector domain: type of organizations

\begin{tabular}{|c|c|}
\hline Reduced term & Similar terms or from the same domain \\
\hline Charities & charitable sector, charities \\
\hline Cooperatives & cooperatives, co-operatives \\
\hline Foundations & $\begin{array}{l}\text { community foundations, private foundations, } \\
\text { company-sponsored foundations, foundations }\end{array}$ \\
\hline Mutuals & mutual \\
\hline NGO & $\begin{array}{l}\text { nongovernmental sector, nongovernmental } \\
\text { organizations, ngo }\end{array}$ \\
\hline NPO & nonprofit, npo \\
\hline Professional association & professional associations, labor unions \\
\hline Social enterprise & social enterprise \\
\hline
\end{tabular}


Table 2 -Dictionary for the nonprofit sector domain, except type of organizations

\begin{tabular}{|l|l|}
\hline Reduced term & Similar terms or from the same domain \\
\hline Accountability & accountability \\
\hline Beneficiary & beneficiaries, beneficiary, clients, client, customers, customer \\
\hline Board of directors & board of directors, directors, board members, board, managers, trustees \\
\hline Community & communities, community \\
\hline Donor & donors, donor \\
\hline Enterprise & enterprises, companies \\
\hline Funder & funders, funder \\
\hline Funding & funding, fundraising, raise funds, donations, grants \\
\hline Governance & governance, governing, governed \\
\hline Government & governments, government \\
\hline Investor & investors, investor \\
\hline Leadership & leadership, leading, leaders, leader \\
\hline Media & media \\
\hline Partner & partnership, partnering, cooperating, cooperation, synergies, partner \\
\hline Peer & peers, peer \\
\hline Professionalization & training, trainers, train, professionalization, professionalism, professionalized \\
\hline Retention & retention, motivation, disengagement, engagement, involvement \\
\hline Satisfaction & dissatisfaction, satisfaction \\
\hline Scholars & scholar, researcher, academics \\
\hline Transparency & transparency \\
\hline Volunteer & volunteers, volunteering, volunteer \\
\hline Worker & paid staff, staff members, employees, workers, worker \\
\hline
\end{tabular}

Table 3 -Dictionary for the reputation domain

\begin{tabular}{|l|l|}
\hline Reduced term & Similar terms or from the same domain \\
\hline Assessment & evaluation, assessment, audit, judgment \\
\hline Credibility & accreditation, credible, reliable, trust \\
\hline Effectiveness & effectiveness, efficiency, performance \\
\hline Evaluator & evaluator, watchdog, auditor \\
\hline Identity & identity, symbolic, symbols \\
\hline Image & perception, image, impression \\
\hline Legitimacy & legitimacy, legitimate, legitimation \\
\hline Outcome & outputs, outcomes, impact, goals, mission \\
\hline Rating & ranting, ranking \\
\hline Risk & fraud, corruption, risk \\
\hline
\end{tabular}


A broadly-defined search was conducted to select peer-reviewed papers in academic journals from the following scientific databases: Scopus, ProQuest, Science Direct, Web of Science, and ABI/INFORM Global. These have consistently been used in previous studies (Liket and Simaens 2013; Manetti 2014; Moxham 2014). The present search excluded editorial notes, book reviews, and all publications other than those in English. The remaining articles' titles and abstracts were manually analyzed to ensure they focus on both nonprofits and reputation.

This procedure resulted in a sample of 217 articles, from which 40 were excluded because the documents' full text did not satisfy the language criterion (i.e., 31 articles) or their content was not accessible. The latter was true of 9 articles, all of which had not been published in the top 10 journals included in our database, resulting in these papers' exclusion from further analyses. Notably, previous studies have also struggled with these constraints (e.g., Liket and Simaens 2013) and applied similar exclusion criteria. The final refined sample had 177 articles published in 136 different journals by 43 different publishers from 1982 to 2016 .

To analyze the evolution of research on nonprofits' reputation, the articles were divided according to publication year into three different periods. These were studies published in the last century; those appearing between 2001 and 2008, covering studies before the global financial crisis when organizational confidence and funding activities were high; and articles from the 2009-2016 crisis and post-crisis periods. During the latter two periods, competition for funding pressured the nonprofit sector into adopting differentiated and more competitive strategies.

To minimize the subjectivity involved in this process of grouping terms under unique, reduced terms, the present research followed validation procedures used in similar studies (Calheiros et 
al. 2017; Moro et al. 2015). Moreover, two experts who are both academics and nonprofit professionals were asked to validate the lexicon and invited to add or remove terms or to group them into single terms. As a result, subcomponents of reputation (e.g., gauge) were removed from the lexicon because they could be a source of potential bias in the analyses. A preliminary analysis of the selected words' frequency in the database was conducted using MAXQDA software for qualitative research. This procedure confirmed that the subcomponents removed were of minor importance because of their residual presence in the articles analyzed.

Text mining reveals knowledge by unveiling patterns hidden in a corpus (Calheiros 2017). When using a lexicon, text mining only searches for terms - which may be composed of one or more words (e.g., "funding" or "fund raiser") — within the texts, thus reducing the dimensionality of the document-term matrix. This avoids the additional challenges posed if all words contained in all documents were considered. The patterns uncovered directly reflect each term's frequency within each document (see Figure 1 above). The lexicon applied was the result of merging the three lexical sections identified in Tables 1 to 3 above. Thus, this simple, yet effective procedure determined exactly how many times each of the relevant terms occurred within each document.

Finally, the patterns identified were input into the latent Dirichlet allocation algorithm, which is currently the most popular topic modeling technique (Moro et al. 2015). This algorithm defines an unsupervised statistical model by considering the relationships between three dimensions (i.e., documents, terms, and topics) based on each term's frequency in each document. The number of topics is the given input, but this needs to be tuned by following Calheiros et al. (2017) and Cortez et al.'s (2018) recommendations. The output is a list of topics characterized by a relationship to each term identified in the lexicon and to each article. 
Both the text mining and topic modeling procedures used the R statistical tool (see https://cran.rproject.org/), which is an open source platform especially well-suited for data analysis because it offers a large number of predeveloped software packages (Cortez 2014). For the text mining, the tm package was selected as it implements text mining functions, while the topicmodels package was chosen for the topic modeling procedure. With these tools and lexicon, different types of nonprofits, stakeholders, or activities were separated into groups to differentiate between them and draw conclusions about trends and gaps in the literature.

\section{Results}

The results show that the number of articles focused on nonprofits' reputation has been increasing, especially in recent years. Moreover, for-profit publishers are predominant among the academic journals analyzed, contributing most of the articles selected. Oxford University Press stands out among the nonprofit publishers of these journals. The contributions made to the literature on the topic under study are dispersed across a broad range of publishers and journals (see Table 4). In addition, these articles appear in journals addressing apparently unrelated scientific fields such as medicine, psychology, or environmental issues.

Table 4 -Characterization of the scientific articles in the reputation field

\begin{tabular}{|l|l|l|l|l|l|}
\hline Journal & Publisher & Articles & $\begin{array}{l}{[1982-} \\
2000]\end{array}$ & $\begin{array}{l}{[2001-} \\
2008]\end{array}$ & $\begin{array}{l}{[2009-} \\
2016]\end{array}$ \\
\hline Nonprofit and Voluntary Sector Quarterly & SAGE & 7 & 1 & 1 & 5 \\
American Journal of Evaluation & Elsevier & 6 & & & 6 \\
Corporate Reputation Review & Springer & 5 & & 4 & 1 \\
Evaluation and Program Planning & Elsevier & 4 & 1 & 1 & 2 \\
Nonprofit Management \& Leadership & Wiley & 4 & 2 & 1 & 1
\end{tabular}




\begin{tabular}{|c|c|c|c|c|c|}
\hline Journal of Nonprofit and Public Sector & Taylor \& & 4 & & 1 & 3 \\
\hline Marketing & Francis Group & & & & \\
\hline Voluntas & Springer & 4 & & & 4 \\
\hline $\begin{array}{l}\text { Public Performance and Management } \\
\text { Review }\end{array}$ & SAGE & 3 & & & 3 \\
\hline Development in Practice & $\begin{array}{l}\text { Taylor \& } \\
\text { Francis Group }\end{array}$ & 3 & 1 & 1 & 1 \\
\hline .. & & - & & & \\
\hline Total & & 177 & 31 & 42 & 104 \\
\hline
\end{tabular}

Note: The publishers and journals with just three or less articles are not presented, for page space optimization purposes only.

The most frequent terms and 12 latent research salient topics are identified, after which different topic trends are discussed. The number of latent topics is not restrictive. Several combinations of topics were experimented and 12 was determined as the optimal number of topics to be used considering the topic mixtures of each document, the significance of the topic present in each article and the level of topic representation of all documents.

\section{Salient topic identification}

Table 5 provides the absolute frequency of the 32 terms in the reputation field in the selected articles, namely, how many times each term occurs in the corpus. Identity stands out as the most cited term, revealing a focus in the literature on organizations' core identity. Image is less frequently used, but its distribution across articles is quite similar to that of identity. Accountability in nonprofits' relationships with their stakeholders has been intensely studied under the scope of board governance responsibilities, while ensuring transparency tends to be largely ignored in the literature on reputation. 
Table 5 -Most relevant terms frequencies for reputation in nonprofits

\begin{tabular}{|c|c|c|c|c|}
\hline$\#$ & Term & $\begin{array}{l}\text { Absolute } \\
\text { frequency } \\
\text { (A) }\end{array}$ & $\begin{array}{l}\text { Number of articles } \\
\text { containing the term } \\
\text { (B) }\end{array}$ & $\begin{array}{l}\text { Average term per } \\
\text { article (ATPA) } \\
\text { (A)/(B) }\end{array}$ \\
\hline 1 & Identity & 1934 & 65 & 30 \\
\hline 2 & Community & 1445 & 132 & 11 \\
\hline 3 & Government & 999 & 114 & 9 \\
\hline 4 & Funding & 977 & 102 & 10 \\
\hline 5 & Image & 899 & 57 & 16 \\
\hline 6 & Accountability & 881 & 69 & 13 \\
\hline 7 & Effectiveness & 672 & 90 & 8 \\
\hline 8 & Satisfaction & 626 & 59 & 11 \\
\hline 9 & Outcome & 441 & 92 & 5 \\
\hline 10 & Donor & 437 & 58 & 8 \\
\hline 11 & Media & 427 & 67 & 6 \\
\hline 12 & Leadership & 417 & 67 & 6 \\
\hline 13 & Volunteer & 381 & 50 & 8 \\
\hline 14 & Risk & 320 & 62 & 5 \\
\hline 15 & Governance & 285 & 54 & 5 \\
\hline 16 & Assessment & 272 & 93 & 3 \\
\hline 17 & Researchers & 251 & 80 & 3 \\
\hline 18 & Enterprise & 225 & 33 & 7 \\
\hline 19 & Legitimacy & 225 & 47 & 5 \\
\hline 20 & Peer & 173 & 22 & 8 \\
\hline 21 & Evaluator & 143 & 25 & 6 \\
\hline 22 & Credibility & 137 & 34 & 4 \\
\hline 23 & Partner & 121 & 44 & 3 \\
\hline 24 & Rating & 119 & 34 & 4 \\
\hline 25 & Transparency & 107 & 42 & 3 \\
\hline 26 & Funder & 92 & 24 & 4 \\
\hline 27 & Retention & 77 & 13 & 6 \\
\hline 28 & Board of directors & 73 & 26 & 3 \\
\hline 29 & Worker & 50 & 19 & 3 \\
\hline 30 & Professionalization & 36 & 11 & 3 \\
\hline 31 & Beneficiary & 31 & 19 & 2 \\
\hline 32 & Investor & 13 & 7 & 2 \\
\hline
\end{tabular}


External stakeholders - especially those bringing resources into nonprofits-play an important role in reputation. The high frequency of stakeholder-related terms, including community, government, and donor, is a clear evidence of this. Perceptions of reputation are, therefore, largely examined from an external stakeholders' viewpoint, while volunteers are most frequently cited at the domestic level. This discrepancy in terms' frequency can best be visualized in a word cloud (see Figure 2), in which the size of a word is proportional to the number of times the term is mentioned in the selected articles.

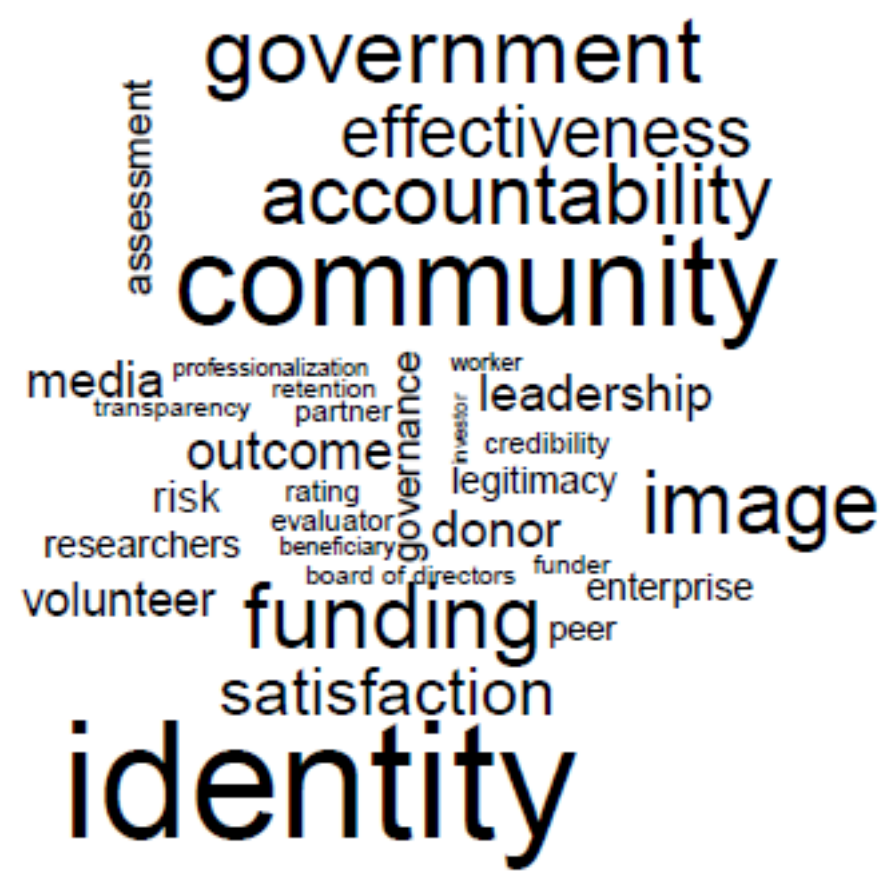

Figure 2 - Word cloud for nonprofits' reputation (Absolute frequency).

Regarding the organization types' frequencies (see Table 6), referring to the NPO's legal status, NGO stands out as the most cited in the corpus. The prominent role these organizations play in international development ensures they develop a permanent, effective relationship with public authorities during the implementation of community projects. Community and government are the second and third most cited terms in the articles mentioning NGOs, which reflects the weight 
these actors exert in NGOs' reputation (see, for example, O'Leary [2016]). The second most cited type of nonprofit is nonprofit organization since this term is extensively used when discussing the state of the art (for a recent example, see Grant and Potoski [2015]). This term also reflects significant, indistinguishable data processing and analyses conducted by scholars while studying nonprofits (see, for example, Carman [2009]).

Table 6-Absolute frequency of the terms related with type of nonprofits

\begin{tabular}{|l|l|l|l|}
\hline Term & $\begin{array}{l}\text { Absolute } \\
\text { frequency } \\
\text { (A) }\end{array}$ & $\begin{array}{l}\text { Number of articles } \\
\text { containing the term } \\
\text { (B) }\end{array}$ & $\begin{array}{l}\text { Average term per } \\
\text { article (ATPA) } \\
\text { (A)/(B) }\end{array}$ \\
\hline NGO & 3694 & 58 & 64 \\
NPO & 2241 & 81 & 28 \\
Charities & 453 & 42 & 11 \\
Cooperatives & 274 & 28 & 10 \\
Social enterprises & 206 & 16 & 13 \\
Foundations & 171 & 49 & 3 \\
Professional association & 79 & 10 & 8 \\
Mutuals & 14 & 4 & 4 \\
\hline
\end{tabular}

The results of this simple word extraction method can be unreliable since extremely frequent terms are not necessarily relevant to the selected domains. Nevertheless, absolute frequency was a starting point from which to examine the frequency of a combination of terms in the collected articles. Table seven shows these data, which facilitated a correlation of nonprofit sector terms with reputation challenges and revealed 12 salient topics. 
Table 7 -Relevant salient topics for nonprofits' reputation and respective terms used

\begin{tabular}{|c|c|c|c|c|c|c|c|}
\hline $\begin{array}{l}\text { Topic \#1 } \\
\text { (25 articles) }\end{array}$ & 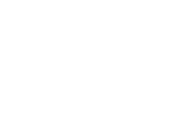 & $\begin{array}{l}\text { Topic \#2 } \\
\text { (24 articles) }\end{array}$ & 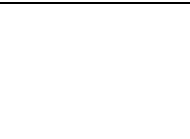 & $\begin{array}{l}\text { Topic \#3 } \\
\text { (23 articles) }\end{array}$ & 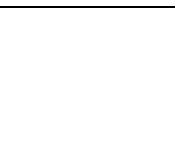 & $\begin{array}{l}\text { Topic \#4 } \\
\text { (18 articles) }\end{array}$ & 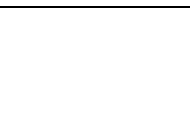 \\
\hline Identity & $(.05 \mid 60)$ & $\begin{array}{l}\text { Effectiveness } \\
\text { Enterprise }\end{array}$ & $\begin{array}{l}(.67 \mid 17) \\
(1.66 \mid 7)\end{array}$ & $\begin{array}{l}\text { Donor } \\
\text { Outcome } \\
\text { Assessment }\end{array}$ & $\begin{array}{l}(.94 \mid 12) \\
(1.11 \mid 9) \\
(2.08 \mid 4)\end{array}$ & Community & $(.06 \mid 28)$ \\
\hline $\begin{array}{l}\text { Topic \#5 } \\
\text { (18 articles) }\end{array}$ & & $\begin{array}{l}\text { Topic \#6 } \\
\text { (14 articles) }\end{array}$ & & $\begin{array}{l}\text { Topic \#7 } \\
\text { (12 articles) }\end{array}$ & & $\begin{array}{l}\text { Topic \#8 } \\
\text { (11 articles) }\end{array}$ & 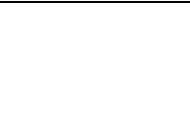 \\
\hline Accountability & $(.55 \mid 36)$ & Image & $(.39 \mid 24)$ & Government & $(.07 \mid 25)$ & Leadership & $(.91 \mid 13)$ \\
\hline Governance & $(2.17 \mid 8)$ & Volunteer & $(1.52 \mid 14)$ & & & Peer & $(1.63 \mid 12)$ \\
\hline Legitimacy & $(2.36 \mid 6)$ & Retention & $(2.92 \mid 5)$ & & & & \\
\hline $\begin{array}{l}\text { Topic \#9 } \\
\text { (10 articles) }\end{array}$ & & $\begin{array}{l}\text { Topic \#10 } \\
\text { (9 articles) }\end{array}$ & & $\begin{array}{l}\text { Topic \#11 } \\
\text { (8 articles) }\end{array}$ & & $\begin{array}{l}\text { Topic \#12 } \\
\text { (5 articles) }\end{array}$ & \\
\hline $\begin{array}{l}\text { Satisfaction } \\
\text { Evaluator }\end{array}$ & $\begin{array}{l}(.31 \mid 23) \\
(1.9 \mid 9)\end{array}$ & $\begin{array}{l}\text { Media } \\
\text { Credibility }\end{array}$ & $\begin{array}{l}(.34 \mid 22) \\
(1.62 \mid 8)\end{array}$ & Funding & $(.18 \mid 44)$ & Risk & $(.2 \mid 35)$ \\
\hline
\end{tabular}

Note: The correlation coefficient between the topic and the term $(\beta)$ is presented in parentheses, as well as the average term cite per article (ATPA). This is shown as ( $\beta \mid$ ATPA). 
Each salient topic's characterization is presented using an integration logic synthesis based on the theoretical perspectives of this study (i.e., corporate reputation and evaluation of nonprofits). In addition, this analysis considers the stakeholders linked to these perspectives and the management strategies considered to leverage nonprofits' interactions with stakeholders.

Salient topic 1's focus is clearly identity, with, on average, a frequency of 60 cites in each of the 25 articles most associated with this topic. The second dimension of reputation (i.e., image) is the focus of salient topic 6 . The 14 relevant articles focus not only on image in isolation but also image from volunteers' perspective or in relation to their retention.

Concerning reputation from the evaluation point of view, three salient topics emerge (i.e., 2, 3, and 9). Salient topic 2 focuses on effectiveness, which appears in 17 articles. In salient topic 3, donor, outcome, and assessment are the most frequent terms in the 23 articles associated. Finally, in salient topic 9 the most representative term is satisfaction, followed by evaluator, which are mentioned together in two out of the ten articles on this topic.

Salient topic 11 comprises the main group of stakeholders who are identified in the literature as often requesting evaluation information, with the most cited term being funding. Regarding salient topic 4, community emerges as the most relevant term, and salient topic 7 gives to the term government a key role.

The 18 articles under salient topic 5 focus on accountability. These articles address issues regarding nonprofit leveraging in terms of external actors, with respect to governance and legitimacy. Salient topic 10 is also related to this subject, but this topic addresses credibility. All nine articles on this topic are associated with media, making this the most cited term. 
Finally, salient topics 8 and 12 contain terms related to management strategies, focusing on leadership or risk issues, respectively.

\section{Salient topic trends}

A longitudinal analysis of the publications by topic (see Table 8) identified topic trends in recent years by their tendency to grow or decrease. The results are presented according to groups of salient topics organized by their tendencies, highlighting the most outstanding examples of each.

Four salient topics (i.e., 3, 6, 7, and 9) show a trend toward more articles in the last eight years examined.

Increased competition for clients, members, and donors has justified the nonprofit sector's use of marketing strategies (Eikenberry and Kluver 2004) and its search for a better understanding of factors affecting nonprofit-donor relationships (i.e., salient topic 3). These factors may include donor trust (Torres-Moraga et al. 2010), donor evaluation focus (Chen 2016), or sectoral reputation (Schloderer et al. 2014). Moreover, the links between donors and outcomes reveal that researchers have also paid attention to strategies donors can use to evaluate funding projects (Wahlén 2014). Researchers have made recommendations for how to determine which evaluation strategy is most appropriate for which circumstances (Howes 1992). 
Table 8 - Longitudinal analysis of nonprofits' reputation literature (number of articles per period and topic)

\begin{tabular}{|c|c|c|c|c|c|c|c|c|}
\hline \multirow[t]{2}{*}{ Topic \# } & \multicolumn{2}{|c|}{ 1982-2000 } & \multicolumn{2}{|c|}{$2001-2008$} & \multicolumn{2}{|c|}{$2009-2016$} & \multicolumn{2}{|l|}{ Overall } \\
\hline & $\begin{array}{l}\mathrm{Nr} . \\
\text { articles }\end{array}$ & $\begin{array}{l}\text { Weight in } \\
\text { publications of the } \\
\text { period }(\%)\end{array}$ & $\begin{array}{l}\text { Nr. } \\
\text { articles }\end{array}$ & $\begin{array}{l}\text { Weight in } \\
\text { publications of the } \\
\text { period }(\%)\end{array}$ & $\begin{array}{l}\text { Nr. } \\
\text { articles }\end{array}$ & $\begin{array}{l}\text { Weight in } \\
\text { publications of the } \\
\text { period }(\%)\end{array}$ & Nr. articles & \begin{tabular}{|l} 
Weight in \\
publications of \\
the period $(\%)$
\end{tabular} \\
\hline Topic 1 & 3 & 9.7 & 8 & 19.0 & 14 & 13.5 & 25 & 14.1 \\
\hline Topic 2 & 2 & 6.5 & 6 & 14.3 & 16 & 15.4 & 24 & 13.6 \\
\hline Topic 3 & 5 & 16.1 & 3 & 7.1 & 15 & 14.4 & 23 & 13.0 \\
\hline Topic 4 & 7 & 22.6 & 4 & 9.5 & 7 & 6.7 & 18 & 10.2 \\
\hline Topic 5 & 1 & 3.2 & 6 & 14.3 & 11 & 10.6 & 18 & 10.2 \\
\hline Topic 6 & 2 & 6.5 & 3 & 7.1 & 9 & 8.7 & 14 & 7.9 \\
\hline Topic 7 & 0 & .0 & 1 & 2.5 & 11 & 10.6 & 12 & 6.8 \\
\hline Topic 8 & 1 & 3.2 & 4 & 9.5 & 6 & 5.7 & 11 & 6.2 \\
\hline Topic 9 & 4 & 12.9 & 1 & 2.4 & 5 & 4.8 & 10 & 5.6 \\
\hline Topic 10 & 4 & 12.9 & 3 & 7.1 & 2 & 1.9 & 9 & 5.1 \\
\hline Topic 11 & 1 & 3.2 & 2 & 4.8 & 5 & 4.8 & 8 & 4.5 \\
\hline Topic 12 & 1 & 3.2 & 1 & 2.4 & 3 & 2.9 & 5 & 2.8 \\
\hline
\end{tabular}


Regarding image and its association with volunteers (i.e., salient topic 6), scholars have focused on explaining stakeholders' perceptions of nonprofits' image and the impact this has on stakeholders' actions. Important determinants of organizational image are the performance of employees responsible for client contact (Nguyen 2006) and the type of information displayed on nonprofits' websites (Huang and $\mathrm{Ku}$ 2016). In addition, image has been explored as a factor explaining organizational behaviors, including lower employee absenteeism (Rho et al. 2015).

The articles on salient topic 7 focus on government and, in the literature on reputation, appear to have been inspired by the global financial crisis beginning in 2008. Studies on this topic started being published in that year, possibly pushed by the new restrictions on public funds distributed to nonprofits. This research has addressed subject matter related to nonprofits' strategies while dealing with governments, including conflict and consensus (Zchout and Tal 2016). Other studies have, among various fields, examined the effect accounting firms' reputation has on nonprofits' income, using loss of reputation to understand how this affects nonprofits' income sources such as governmental grants (Harris and Krishnan 2012).

Salient topic 9's articles focus on satisfaction, examining determinants of this among volunteers (Tidwell 2005) and customers (Xie et al. 2010), as well as other actors. This topic also has a relationship with the term evaluator, which is equated to watchdog and auditor entities. While this correlation is clear for salient topic 9 , an emphasis on the role of watchdogs and auditors in assessment processes and, consequently, in nonprofits' reputation appears in various areas of research, i.e., in other research salient topics. These include peer reputation's (i.e., salient topic 8) influence on donations through Charity Navigator ratings (Grant 2015) or performance evaluation practices (i.e., salient topic 2) in which nonprofits adopt the general standards determined by nonprofit rating agencies (Eckerd and Moulton 2011). 
Articles on salient topics 4 and ten have decreased in number over the period under analysis.

Closer scrutiny was needed to find out what events originally triggered interest in these projects. Publications in media-related topic (i.e., salient topic 10), in the last century, first focused on understanding media coverage (e.g., number of stories, length of articles, and advertising space) in newspapers (e.g., Schmidt 1993). Scholars have since turned their attention to social media's impacts ((McPherson 2015).

Regarding articles on community (i.e., salient topic 4), studies first explored community mechanisms that support economic development. For example, community financing of insurance schemes (Atim 1999). At the beginning of this century, articles focused on the approaches nonprofits adopt to encourage community participation (e.g., Williams 2004). Most recently, researchers has examined nonprofit-community partnerships, emphasizing the benefits they offer both groups (Bell et al. 2015).

An analysis was carried out of how the weight of the total of each salient topic's articles has evolved, revealing that risk's (i.e., salient topic 12) articles have the lowest weight. Despite a general upward trend in risk research, the interest appears to have diminished in 2016, perhaps indicating that scholars are now having to deal with more challenges in this field.

\section{In-depth review of main articles and critical analysis}

The above-described automated text analyses facilitated the extraction of relevant knowledge that highlights present and future research and practices regarding nonprofits' reputation. In addition, a critical analysis of the trends and shifts in the literature and an in-depth review of the most significant articles within each salient topic facilitated the identification of benefits gained 
from research on these topics. These results could help nonprofits manage their organizational reputation and scholars make further advances in knowledge. In all, four research paradigm changes that affect the nonprofit sector were found, as discussed below.

From absolute confidence in nonprofits to intense scrutiny of organizations. In the 1970s, Kotler and Murray (1975) highlighted three tendencies in nonprofits: flexibility, innovation, and independence. Some authors claimed that these characteristics meant that the output of these organizations' activities is of greater value than that of for-profit companies (Ortmann and Schlesinger 1997). Other experts, however, refuted this idea, stating that nonprofits "are not necessarily more intrinsically trustworthy than for-profit organizations" (Halfpenny 2000, p. 142). The era of blind trust in the nonprofit sector thus faded into the past.

In line with resource dependence theory (Pfeffer and Slancik 1978), nonprofits' behavior has become increasingly conditioned by how much weight external funds have in the nonprofits' revenues. The present study confirmed that external stakeholders are becoming more and more important for nonprofits' activities. Different stakeholders are among the most cited terms (see Table 5 above), and "community" and "government" are terms with key roles in salient topics 4 and 7, respectively (see Table 7 above). As governments have now assumed the role of principal philanthropists, scholars have shifted their focus to the effect of public funding on nonprofit governance (Guo 2007).

In addition, market pressures, donor dependence, boards of directors' central role, staff professionalization, and critical contributions for communities are transforming accountability challenges in the nonprofit sector (Keating and Frumkin 2003). To achieve their accountability goals, nonprofits must be transparent. The results show that online technologies serve not only to 
disclose information to stakeholders but also to receive feedback from users - a bi-directional flow of communication (Dumont 2013).

Nonetheless, the term "transparency" is one of the least cited terms in the literature (see Table 5 above). Such lack of reputation research focusing on transparency could be a sign that advances are being hampered by significant barriers. Possible explanations are countries' diverse accountability and transparency requirements or low levels of awareness among stakeholders about these issues (Anheier 2013). Governments need to agree on evaluation criteria for nonprofits' transparency and accountability, moving toward introducing global directives on information disclosure. And nonprofit managers must be aware of their importance and able to put in practice actions that increase transparency and accountability levels of the nonprofits.

In parallel, more research is needed to understand how transparency practices can contribute to construct and protect organizational reputation. The theoretical development can be achieved if nonprofits develop closer cooperation with scholars by letting go of their reluctance to share data with researchers and participating in surveys, case studies, or tests of theoretical models.

Otherwise, the failures in nonprofit evaluation systems, such as those developed by private rating agencies outside academia (Ling and Neely 2013), will never be corrected.

From irreproachable institutes to risky organizations. The public, for-profit, and nonprofit sectors differ in many respects, but boards and managers face similar challenges when running both businesses and nonprofits. These challenges include, among other risk sources, preventing and responding to equipment breakdowns, vehicle incidents, professional liabilities, and physical losses or damage to human resources. These circumstances can impede projects' completion, 
which can negatively affect nonprofits' reputation, especially with entities financing these projects. Therefore, the nonprofit sector is under pressure to implement risk management.

This strategy is also justified as a response to outside environmental constraints. These include (1) limited and unstable volunteers, material, and financial resources; (2) social alliances for fundraising (Martínez 2003); and (3) vulnerable, problematic conditions among the populations served (Herman et al. 2004). Linking strategies to deal with these challenges and understanding their effects on stakeholders' perceptions of nonprofits should form a natural concentration of studies in the literature on nonprofits' reputation, yet publications on nonprofit risk management are still scarce. Notably, risk is the term most strongly associated with salient topic 12 , but this is the topic with the least articles (see Table 7 above). Moreover, the topic trends analysis revealed that interest in this topic weakened in 2016.

Based on such results, and as suggested earlier regarding transparency, risk management theory can only advance if nonprofits focus on ensuring that sufficient information is made available for research. Nonprofit managers' reluctance to share data with scholars in this area is potentially stronger because the information needed may reveal vulnerabilities that nonprofits do not want to disseminate among stakeholders, namely, investor-donors and peer nonprofits. Although, managers must understand that in a long term perspective the collaboration with researchers may benefit their organizations.

From paper media to online social media. Until the mid-2000s, the literature on nonprofits explored their exposure to mass media but not to social media. Indeed, the latter term did not even appear in the nonprofit lexicon until recently (Smith 2006). Currently, articles reveal that scholars are looking at the way interactions in online media influence organizational image 
development. Although the present study found media as a topic trend (i.e., salient topic 10) in the literature on nonprofit reputation, this topic is decreasing weight (see Tables 7 and 8). Given the role social media is now starting to play in decisions about donations to nonprofits (Saxton and Wang 2014), media theory still has considerable room to grow. This is especially true with respect to how reputation can mediate these decision-making processes and how reputation can be affected by interactions in social media. Given the Web capacity's importance to donors (Saxton 2014), nonprofits' managers need to develop effective social network techniques as part of their relationship-marketing strategies and recruit qualified employees to counteract any bias against technology.

\section{From exploring representative organizations to focusing on differences and similarities.}

Regarding the type of nonprofits, NGO is by far the most cited term, revealing that many scholars have opted to use NGO to label organizations when studying nonprofit sector topics (see Table 6). However, NGOs are typically niche organizations because of their political and institutional roles specializing in international crisis mediation and intergovernmental diplomacy, which differs from the primary roles of other nonprofits (Salamon 2016). These particularities underline the need for research aiming to understand the variations in size, sector, and mission that characterize specific organizations (Lecy 2012) and their sociodemographic environments (Meijer 2009). The findings of these future studies need to be representative enough for generalization to other nonprofits. This is why exploring both differences in organizational and environmental characteristics and similarities across groups of nonprofits can be considered attractive avenues for future research (Schloderer 2014). 


\section{Theoretical and managerial implications}

Four implications emerge from the study's results from both managerial and academic perspectives. First, when nonprofits seek to strengthen their reputations, their managers need to develop effective risk, Internet, and social network management skills given that the traditional patterns of engaging in non-risky behaviors and only using offline media communication strategies are currently inadequate. Second, risk management studies constitute a new salient topic in the literature on nonprofits' reputation, but advances are needed in both risk management theory and practice, which can best be achieved through cooperative arrangements between nonprofits and scholars.

Third, scholars are devoting increased attention to formulating a clearer conceptualization of the nonprofit sector, leading to stronger theoretical frameworks in each subsequent study. In this context, researchers must consider not only the sector's most common core institutions or national trends but also the terms most closely related to the entire sector. This can be achieved by making use of the lexicon developed and validated by experts in the present study.

Last, the identification of salient topics and in-depth review of the relevant articles written over the years by nonprofit reputation researchers in combination revealed active and non-active topics, giving scholars and practitioners a bird's-eye view of the literature on nonprofits' reputation. This combined approach avoided the mistake of overlooking significant constructs and trends. The results could also help increase awareness of the multiple terms and topics used in this field of research. This information must be considered before engaging in further studies in order to support decisions about, for instance, definitions of research questions or topics, thereby allowing researchers to deal more directly with unexplored topics or unanswered challenges. Thus, by 
contributing to more firmly grounded research on reputational aspects of nonprofit organizations, the present study's findings could assist nonprofits' managers in improving their reputation management strategies and increasing positive outcomes.

\section{Conclusion}

This article began by arguing that the field of research on nonprofits' reputation lacks a comprehensive map of the knowledge that researchers have produced so far. To form a deeper and broader understanding of advances in theories of organizational reputation among nonprofits, relevant articles in this scientific field were selected based on a search using a set of proposed and validated terms that refer to reputation-related topics and organizations in the nonprofit sector.

The analyses conducted addressed two research questions. Regarding the first, the methodology applied successfully identified 12 salient topics in research on nonprofits' reputation, confirming that text mining and topic modeling are useful techniques providing scholars and practitioners with insights into the large body of literature in this field. By conducting automated analyses of the entire academic literature directly linked to research on nonprofits' reputation, this study was able to outline the research gaps, trends, and challenges scholars and practitioners currently face in this area. The results thus provide a theoretical synthesis of research topics.

Regarding the second research question, the in-depth analyses of the most important articles in each salient topic supported conclusions on how nonprofits' managers should develop better strategies when competing for reputational status. The findings also indicate further paths for scholars seeking to advance in generating further knowledge in this field of research. 
First, the relationships between scholars and professionals must be based on collaborative arrangements to facilitate advances in evaluation methods and risk management mechanisms dealing with sectoral and organizational reputation. The risks identified in the nonprofit sector suggest that the models of nonprofits' reputation developed in the literature need to consider risk factors in multilevel and multidisciplinary analyses, thereby enriching the existing theories.

Second, as online media are increasingly pervasive in society, competencies in the field of technology have become critical to nonprofits' success, not only to disclose information to stakeholders but also to receive feedback and adjust relationship-marketing strategies accordingly. Nonprofits can use the Internet as a strategic tool to shape their media reputations, using it to gain competitive advantages.

Last, the knowledge created within the nonprofit sector can only be properly applied by taking into consideration differences between nonprofits' age, role, mission, and communities served. Highlighting differences and finding similarities between these organizations are research challenges that need to be addressed in future studies.

These findings identify challenges for both scholars and practitioners. Greater openness could promote cooperative alliances between these communities, allowing them to gain a deeper understanding of nonprofits' reputation. The selection process of relevant articles in this literature review was based on reasoned decisions, but these choices may be considered limitations by other scholars who favor alternative paths. Different databases or the inclusion of nonscientific literature might have been valid options for determining the article sample used in the text mining analysis. 
These alternatives represent opportunities for future research on nonprofits, which could make use of the lexicons developed and validated by experts for the present study and which could extend beyond the field of reputation research. 


\section{References}

Anheier, H. K., Hass, R., \& Beller, A. (2013). Accountability and Transparency in the German Nonprofit Sector: A Paradox? International Review of Public Administration, 18(3), 69-84. https://doi.org/10.1080/12294659.2013.10805264

Ashcroft, L. (2010). Marketing strategies for visibility. Journal of Librarianship and Information Science, 42(2), 89-96. https://doi.org/10.1177/0961000609351365

Atim, C. (1999). Social movements and health insurance: A critical evaluation of voluntary, nonprofit insurance schemes with case studies from Ghana and Cameroon. Social Science and Medicine, 48(7), 881-896. https://doi.org/10.1016/S0277-9536(98)00390-6

Barnett, M. L., Jermier, J. M., \& Lafferty, B. A. (2006). Corporate reputation: The definitional landscape. Corporate Reputation Review, 9(1), 26-38. https://doi.org/10.1057/palgrave.crr.1550012

Bekkers, R., \& Wiepking, P. (2010). A Literature Review of Empirical Studies of Philanthropy: Eight Mechanisms That Drive Charitable Giving. Nonprofit and Voluntary Sector Quarterly, 40(5), 924-973. https://doi.org/10.1177/0899764010380927

Bell, K., Tanner, J., Rutty, J., Astley-Pepper, M., \& Hall, R. (2015). Successful partnerships with third sector organisations to enhance the healthcare student experience: A partnership evaluation. Nurse Education Today, 35(3), 530-534. https://doi.org/10.1016/j.nedt.2014.12.013

Bronzetti, G., \& Veltri, S. (2013). Intellectual capital reporting in the Italian non-profit sector: analysing a case study. Journal of Intellectual Capital, 14(2), 246-263. 
https://doi.org/10.1108/14691931311323878

Burger, R. (2012). Reconsidering the case for enhancing accountability via regulation. Voluntas, 23(1), 85-108. https://doi.org/10.1007/s11266-011-9238-9

Calheiros, A. C., Moro, S., \& Rita, P. (2017). Sentiment Classification of Consumer-Generated Online Reviews Using Topic Modeling. Journal of Hospitality Marketing \& Management, 26(7), 675-693. https://doi.org/10.1080/19368623.2017.1310075

Campbell, J. L. (2007). Why would corporations behave in socially responsible ways? An of corporate theory institutional social responsibility. Academy of Mamagement Review, 32(3), 946-967. https://doi.org/10.2307/20159343

Carman, J. G. (2009). Nonprofits, Funders, and Evaluation: Accountability in action. The American Review of Public Administration, 39(4), 374-390. https://doi.org/10.1002/nml.11203

Carman, J. G. (2011). Understanding evaluation in nonprofit organizations. Public Performance \& Management Review, 34(3), 543-553. https://doi.org/10.2753/PMR1530-9576340302

Carvalho, A. O., Rodrigues, L. L., \& Branco, M. C. (2017). Factors Influencing Voluntary Disclosure in the Annual Reports of Portuguese Foundations. Voluntas (Vol. 28). https://doi.org/10.1007/s11266-017-9883-8

Chen, Q. (2016). Director Monitoring of Expense Misreporting in Nonprofit Organizations: The Effects of Expense Disclosure Transparency, Donor Evaluation Focus and Organization Performance. Contemporary Accounting Research, 33(4), 1601-1624. https://doi.org/10.1111/1911-3846.12218 
Christensen, T., Lægreid, P., \& Rykkja, L. H. (2016). Organizing for crisis management:

Building governance capacity and legitimacy. Public Administration Review, 76(6), 887897. https://doi.org/10.1111/puar.12558

Comyns, B., \& Franklin-Johnson, E. (2018). Corporate Reputation and Collective Crises: A Theoretical Development Using the Case of Rana Plaza. Journal of Business Ethics, 150, 159-183. https://doi.org/10.1007/s10551-016-3160-4

Cortez, P. (2014). Modern optimization with R. Springer.

Cortez, P., Moro, S., Rita, P., King, D., \& Hall, J. (2018). Insights from a text mining survey on Expert Systems research from 2000 to 2016. Expert Systems, 35(e12280), 1-10. https://doi.org/10.1111/exsy.12280

Crofts, K., \& Bisman, J. (2010). Interrogating accountability: An ilustration of the use of Leximancer software for qualitative data analysis. Qualitative Research in Accounting \& Management, 7(2), 180-207. https://doi.org/10.1108/11766091011050859

Curran, R., Taheri, B., MacIntosh, R., \& O'Gorman, K. (2016). Nonprofit Brand Heritage Its Ability to Influence Volunteer Retention, Engagement, and Satisfaction. Nonprofit and Voluntary Sector Quarterly, 45(6), 1234-1257. https://doi.org/10.1177/0899764016633532

Defourny, J., Gronbjerg, K., Meijs, L., Nyssens, M., \& Yamauchi, N. (2016). Voluntas Symposium: Comments on Salamon and Sokolowski's Re-conceptualization of the Third Sector. Voluntas, 27(4), 1546-1561. https://doi.org/10.1007/s11266-016-9743-y

Dimaggio, P. J., \& Powell, W. W. (1983). The iron cage revisited: Institutional and collective rationality in organizational fields. American Sociological Review, 48(2), 147-160. 
Dumont, G. E. (2013). Transparency or Accountability? The Purpose of Online Technologies for Nonprofits. International Review of Public Administration, 18(3), 7-29. https://doi.org/10.1080/12294659.2013.10805261

Eckerd, A., \& Moulton, S. (2011). Heterogeneous roles and heterogeneous practices: Understanding the adoption and uses of nonprofit performance evaluations. American Journal of Evaluation, 32(1), 98-117. https://doi.org/10.1177/1098214010381780

Eikenberry, A. M., \& Kluver, J. D. (2004). The marketization of the nonprofit sector: Civil society at risk? Public Administration Review, 64(2), 132-140.

Gent, S. E., Crescenzi, M. J. C., Menninga, E. J., \& Reid, L. (2015). The reputation trap of NGO accountability. International Theory, 7(3), 426-463. https://doi.org/10.1017/S1752971915000159

Gilstrap, C. A., \& Smith, S. M. (2016). Identity Tensions During an NGO Name Change: How Managers Experience an International Organization's Rebranding Effort. International Journal of Strategic Communication, 10(5), 445-461. https://doi.org/10.1080/1553118X.2016.1225302

Grant, L. E., \& Potoski, M. (2015). Collective reputations affect donations to nonprofits. Journal of Policy Analysis and Management, 33(4), 835-852. https://doi.org/10.1002/pam.21868

Guo, C. (2007). When Government Becomes the Principal Philanthropist: Th eEffects of Public Funding on Patterns of Nonprofit Governance. Public Administration Review, 67(3), 45871. https://doi.org/10.1111/j.1540-6210.2007.00729.x

Halfpenny, P. (2000). Trust, Charity and Civil Society. In F. Tonkiss, A. Passey, N. Fenton, and 
L. C. Hems (Eds.), Trust and Civil Society (pp. 132-150). London: Palgrave Macmillan UK. https://doi.org/10.1057/9780333981795_8

Harris, E., \& Krishnan, J. (2012). The Impact of Tarnished Auditor Reputation on Nonprofit Income. International Journal of Auditing, 16(2), 130-146. https://doi.org/10.1111/j.10991123.2011.00445.x

Heller, N. A. (2008). The influence of reputation and sector on perceptions of brand alliances of nonprofit organizations. Journal of Nonprofit \& Public Sector Marketing, 20(1), 15-36. https://doi.org/10.1080/10495140802165345

Herman, M. L., Head, G. L., Jackson, P. M., Fogarty, T. E., \& Kronstadt, J. (2004). Managing risk in nonprofit organizations : A comprehensive guide. Hoboken, NJ: John Wiley and Sons.

Howes, M. (1992). Linking paradigms and practice: Key issues in the appraisal, monitoring and evaluation of British NGO Projects. Journal of International Development, 4(4), 375-396. https://doi.org/10.1002/jid.3380040404

Huang, S., \& Ku, H. (2016). Brand Image Management for Nonprofit Organizations : Exploring the Relationships Between Websites, Brand Images and Donations. Journal of Electronic Commerce Research, 17(1), 80-96.

Hull, C. E., \& Lio, B. H. (2006). Innovation in non-profit and for-profit organizations: Visionary, strategic, and financial considerations. Journal of Change Management, 6(1), 53-65. https://doi.org/10.1080/14697010500523418

Hume, C., \& Hume, M. (2016). What about us? Exploring small to medium Australian not for- 
profit firms and knowledge management. Journal of Knowledge Management, 20(1), 104124. https://doi.org/10.1108/JKM-12-2014-0497

Kaplan, R. S. (2001). Strategic Performance Measurement and Management in Nonprofit Organizations. Nonprofit Management \& Leadership, 11(3), 354. https://doi.org/10.1002/nml.11308

Keating, E. K., \& Frumkin, P. (2003). Reengineering Nonprofit Financial Accountability: Toward a More Reliable Foundation for Regulation. Public Administration Review, 63(1), 3-15. https://doi.org/10.1111/1540-6210.00260

Kendall, J., \& Knapp, M. (2000). Measuring the performance of voluntary organizations. Public Management Review, 2(1), 105-132. https://doi.org/10.1080/14719030000000006

Kotler, P., \& Murray, M. (1975). Third sector management - The role of marketing. Public Administration Review, 35(5), 467-472. https://doi.org/10.2307/974176

Lecy, J. D., Schmitz, H. P., \& Swedlund, H. (2012). Non-governmental and not-for-profit organizational effectiveness: A modern synthesis. Voluntas, 23(2), 434-457. https://doi.org/10.1007/s11266-011-9204-6

Liket, K., \& Simaens, A. (2013). Battling the devolution in the research on corporate philanthropy. Journal of Business Ethics, 126(2), 285-308. https://doi.org/10.1007/s10551013-1921-x

Ling, Q., \& Neely, D. G. (2013). Charitable Ratings and Financial Reporting Quality: Evidence From the Human Service Sector. Journal of Public Budgeting, Accounting \& Financial Management, 25(1), 69-90. 
Maier, F., Meyer, M., \& Steinbereithner, M. (2016). Nonprofit organizations becoming businesslike: A systematic review. Nonprofit and Voluntary Sector Quarterly, 45(1), 64-86. https://doi.org/10.1177/0899764014561796

Manetti, G. (2014). The Role of Blended Value Accounting in the Evaluation of Socio-Economic Impact of Social Enterprises. Voluntas, 25(2), 443-464. https://doi.org/10.1007/s11266012-9346-1

Martínez, C. V. (2003). Social alliances for fundraising: How spanish nonprofits are hedging the risks. Journal of Business Ethics, 47(3), 209-222. https://doi.org/10.1023/A:1026212902564

McPherson, E. (2015). Advocacy Organizations' Evaluation of Social Media Information for NGO Journalism The Evidence and Engagement Models. American Behavioral Scientist, 59(1), 124-148. https://doi.org/10.1177/0002764203255211

Meijer, M.-M. (2009). The Effects of Charity Reputation on Charitable Giving. Corporate Reputation Review, 12(1), 33-42. https://doi.org/10.1057/crr.2009.5

Mitchell, G. E. (2015). The attributes of effective NGOs and the leadership values associated with a reputation for organizational effectivenes. Nonprofit Management \& Leadership, 26(1), 39-57. https://doi.org/10.1002/nml

Mitchell, G. E., \& Stroup, S. S. (2016). The reputations of NGOs: Peer evaluations of effectiveness. The Review of International Organizations, 1-23. https://doi.org/10.1007/s11558-016-9259-7

Moro, S., Cortez, P., \& Rita, P. (2015). Business intelligence in banking: A literature analysis 
from 2002 to 2013 using text mining and latent Dirichlet allocation. Expert Systems with Applications, 42(3), 1314-1324. https://doi.org/10.1016/j.eswa.2014.09.024

Moro, S., \& Rita, P. (2018). Brand strategies in social media in hospitality and tourism. International Journal of Contemporary Hospitality Management, 301(1), 343-364. https://doi.org/https://doi.org/10.1108/IJCHM-07-2016-0340

Moxham, C. (2014). Understanding third sector performance measurement system design: a literature review. International Journal of Productivity and Performance Management, 63(6), 704-726. https://doi.org/10.1108/IJPPM-08-2013-0143

Nguyen, N. (2006). The Perceived Image of Service Cooperatives: An Investigation in Canada and Mexico. Corporate Reputation Review, 9(1), 62-78. https://doi.org/10.1057/palgrave.crr.1550010

O 'leary, S. (2016). Grassroots accountability promises in rights-based approaches to development: The role of transformative monitoring and evaluation in NGOs. Accounting, Organizations and Society, 1-21. https://doi.org/10.1016/j.aos.2016.06.002

Ortmann, A., \& Schlesinger, M. (1997). Trust, repute and the role of non-profit enterprise. Voluntas, 8(2), 97-119. https://doi.org/10.1007/BF02354189

Padanyi, P., \& Gainer, B. (2003). Peer reputation in the nonprofit sector: Its role in nonprofit sector management. Corporate Reputation Review, 6(3), 252-265. https://doi.org/10.1057/palgrave.crr.1540204

Pfeffer, J., \& Slancik, G. R. (1978). Social control of organizations: A resource dependence perspective. The External Control of Organizations: A Resource Dependence Perspective. 
New York: Harper \& Row.

Poister, T. H., \& Thomas, J. C. (2007). The wisdom of crowds: Learning from administrators' predictions of citizen perceptions. Public Administration Review, 67(2), 279-289. https://doi.org/10.1111/j.1540-6210.2007.00713.x

Rho, E., Yun, T., \& Lee, K. (2015). Does organizational image matter? Image, identification, and employee behaviors in public and nonprofit organizations. Public Administration Review, 75(3), 421-431. https://doi.org/10.1111/puar.12338

Salamon, L. M., \& Sokolowski, S. W. (2016). Beyond nonprofits: Re-conceptualizing the third sector. Voluntas, 27(4), 1515-1545. https://doi.org/10.1007/s11266-016-9726-z

Sarstedt, M., \& Schloderer, M. P. (2010). Developing a measurement approach for reputation of non-profit organizations. International Journal of Nonprofit and Voluntary Sector Marketing, 15(3), 276-299. https://doi.org/10.1002/nvsm.389

Saxton, G. D., \& Wang, L. (2014). The Social Network Effect: The Determinants of Giving Through Social Media. Nonprofit and Voluntary Sector Quarterly, 43(5), 850-868. https://doi.org/10.1177/0899764013485159

Schloderer, M. P., Sarstedt, M., \& Ringle, C. M. (2014). The relevance of reputation in the nonprofit sector: the moderating effect of socio-demographic characteristics. International Journal of Nonprofit and Voluntary Sector Marketing, 19(2014), 110-126. https://doi.org/10.1002/nvsm

Schmidt, D. E. (1993). Public opinion and media coverage of labor unions. Journal of Labor Research, 14(2), 151-164. https://doi.org/10.1007/BF02685662 
Smith, D. H., Stebbins, R. A., \& Dover, M. A. (2006). Nonprofit terms \& concepts. Bloomington, IN: Indiana University Press.

Tidwell, M. V. (2005). A social identity model of prosocial behaviors within nonprofit organizations. Nonprofit Management \& Leadership, 15(4), 449-467. https://doi.org/10.1002/nml.82

Torres-Moraga, E., Vásquez-Parraga, A. Z., \& Barra, C. (2010). Antecedents of donor trust in an emerging charity sector: The role of reputation, familiarity, opportunism and communication. Transylvanian Review of Administrative Sciences, 6(29), 159-177.

Tremblay-Boire, J., Prakash, A., \& Gugerty, M. K. (2016). Regulation by reputation: Monitoring and sanctioning in nonprofit accountability clubs. Public Administration Review, 76(5), 712-722. https://doi.org/10.1111/puar.12539

Wahlén, C. B. (2014). Constructing Conservation Impact: Understanding Monitoring and Evaluation in Conservation NGOs. Conservation and Society, 12(1), 77-88. https://doi.org/10.4103/0972-4923.132133

Willems, J. (2016). Organizational Crisis Resistance: Examining Leadership Mental Models of Necessary Practices to Resist Crises and the Role of Organizational Context. Voluntas, 27(6), 2807-2832. https://doi.org/10.1007/s11266-016-9753-9

Williams, C. C. (2004). Community capacity building: A critical evaluation of the third sector approach. Review of Policy Research, 21(5), 729-739. https://doi.org/10.1111/j.15411338.2004.00104.x

Witesman, E. M. (2016). An Institutional Theory of the Nonprofit: Toll Goods and Voluntary 
Action. Nonprofit and Voluntary Sector Quarterly, 45(4S), 97S-115S.

https://doi.org/10.1177/0899764016651729

Xie, Y., Hui, C. L., \& Ng, S. F. (2010). The evaluation of quality attributes of NPO products: A case in medical garments. Total Quality Management \& Business Excellence, 21(5), 517535. https://doi.org/10.1080/14783363.2010.481515

Zchout, S. L., \& Tal, A. (2016). Conflict versus consensus strategic orientations among environmental NGOs: An empirical evaluation. Voluntas, 28(3), 1110-1134.

https://doi.org/10.1007/s11266-016-9723-2 
Appendix 1 - Search query

(reputation OR image OR identity OR opinion OR judgment OR evaluation OR estimation OR belief) AND ("nongovernmental org*" OR “ngo*” OR “charities” OR "nonprofit*” OR “npo*” OR “foundations” OR "association*” OR "civic org*” OR "social org*” OR "religious congregation*” OR "faith based org*” OR "volunteer promotion org*” OR "advocacy org*” OR "labor union*” OR “cooperatives" OR “mutuals” OR “social enterprise*” OR “voluntary sector” OR “independent sector” OR "third sector” OR “civil society sector” OR “tax-exempt sector” OR “not-for-profit” OR “philanthropic sector” OR “social sector” OR "voluntary org*” OR “public interest group*” OR “public benefit entit*” OR “donee org*” OR “membership org*” OR “professional org*” OR “social org*” OR “civic org*” OR “social economy”). 